\title{
Characterization of Distinct Tombusviruses that Cause Diseases of Lettuce and Tomato in the Western United States
}

\author{
C. Obermeier, J. L. Sears, H. Y. Liu, K. O. Schlueter, E. J. Ryder, J. E. Duffus, S. T. Koike, and G. C. Wisler
}

First, second, third, fourth, fifth, sixth, and eighth authors: USDA-ARS, 1636 E. Alisal St., Salinas, CA 93905; and seventh author: University of California, Cooperative Extension, 1432 Abbott St., Salinas 93901.

Current address of C. Obermeier: Humboldt-Universität zu Berlin, Institut für Gartenbauwissenschaften, Fachgebiet Phytomedizin, Lentzeallee 55-57, D-14195 Berlin, Germany.

Current address of G. C. Wisler: Department of Plant Pathology, University of Florida, Gainesville 32611.

Accepted for publication 13 April 2001.

\begin{abstract}
Obermeier, C., Sears, J. L., Liu, H. Y., Schlueter, K. O., Ryder, E. J., Duffus, J. E., Koike, S. T., and Wisler, G. C. 2001. Characterization of distinct tombusviruses that cause diseases of lettuce and tomato in the western United States. Phytopathology 91:797-806.

A soilborne disease of lettuce, associated with necrosis and dieback, has been found with increasing frequency in California and Arizona over the last 10 years. An isometric virus, serologically related to Tomato bushy stunt virus (TBSV), was consistently isolated from lettuce plants with these disease symptoms. Back-inoculation to healthy lettuce plants and subsequent reisolation of the virus from symptomatic lettuce leaves suggested that this virus was the causal agent of this disease. A tombusvirus was also associated with a necrosis disease of greenhousegrown tomatoes in Colorado and New Mexico. Complementary DNA representing the $3^{\prime}$ end of viral genomic RNAs recovered from diseased lettuce and tomato plants had identical nucleotide sequences. However, these sequences were divergent (12.2 to $17.1 \%)$ from sequences of the
\end{abstract}

ABSTRACT previously described strains of TBSV, Petunia asteroid mosaic virus (PAMV), Artichoke mottled crinkle virus, and Carnation Italian ringspot virus. Additional tombusvirus isolates were recovered from diseased lettuce and tomato plants and these were most closely related to the TBSV-cherry strain (synonymous with PAMV) and to Cucumber necrosis virus based on comparison of $3^{\prime}$-end sequences ( 0.1 to $0.6 \%$ and 4.8 to $5.1 \%$ divergence, respectively). Western blot analysis revealed that the new tombusvirus isolated from diseased lettuce and tomato plants in the western United States is serologically distinct from previously described tombusvirus species and strains. Based on genomic and serological properties, we propose to classify this virus as a new tombusvirus species and name it Lettuce necrotic stunt virus.

Additional keywords: brown blight, Cymbidium ringspot virus, eggplant, Olpidium bornovanus, soilborne viruses, sugar beet, virus resistance, waterborne viruses.
Tomato bushy stunt virus (TBSV) is the type member of the genus Tombusvirus within the family Tombusviridae. TBSV was first isolated from greenhouse-grown tomato (Lycopersicon esculentum Mill.) in Ireland in 1935 (42). Until the mid-1960s, TBSV was occasionally found in tomato crops in England $(33,34)$, but was not considered economically important. Since then, TBSV and related viruses have been isolated from a wide range of other crops and ornamental plants (28-30). Over the last 30 years, tombusviruses were reported to cause economically important diseases in greenhouse- and field-grown tomato crops in Italy (12), Argentina (38), Mexico (31), Morocco (9), Portugal (4), Tunisia (6), United States (California) (11), and Spain (27). TBSV has also incited disease epidemics in eggplant (Solanum melongena L.) in Tunisia (6) and Spain (27) and in pepper (Capsicum annuum) in Tunisia (6). Distinct strains of TBSV were responsible for disease outbreaks in tomato and eggplant in Spain (27). Although tombusviruses were never reported as the causal agent of a disease in lettuce (Lactuca sativa L.) crops before, they have

Corresponding author: C. Obermeier

E-mail address: christian.obermeier@agrar.hu-berlin.de

The mention of firm names or trade products does not imply endorsement or recommendation by the U.S. Department of Agriculture over other firms or similar products not mentioned.

Publication no. P-2001-0524-01R

This article is in the public domain and not copyrightable. It may be freely reprinted with customary crediting of the source. The American Phytopathological Society, 2001. been isolated together with other viruses from diseased lettuce plants in Czechoslovakia and Turkey $(35,50)$.

A soilborne disease of lettuce characterized by chlorosis, mottling, and necrosis of older leaves, general stunting, and dieback was first reported from California and Arizona in the 1920s in crisphead lettuce cv. New York. This disease was referred to as "brown blight" (3,17-20), but the causal agent of this disease was not identified because it disappeared after introduction of resistant crisphead lettuce cv. Imperial. During the mid-1980s and early 1990s a soilborne disease with symptoms similar to brown blight appeared in the Salinas Valley and other lettuce growing areas in California and Arizona (26,36). The disease was called lettuce dieback disease. Affected fields in the Salinas Valley were mainly located close to the Salinas River in areas that, in recent years, had been flooded during the winter months. A disease of greenhouse-grown tomatoes, characterized by chlorosis and necrotic speckling of leaves, leaf curling and chlorosis, necrosis of inflorescence, flower abortion, and internal browning and necrosis of the fruit, has also been repeatedly observed in Colorado and New Mexico since $1997(48,49)$.

Since the tombusvirus group was established in 1971 with the TBSV tomato isolate as the type species, it has been argued whether other serologically related tombusvirus isolates from artichoke, carnation, petunia, pelargonium, and other crops are distinct tombusvirus species or strains of TBSV (10,28-30). Classification of a distinct tombusvirus species has been based mainly on differences in serology and electrophoretic mobilities of viral particles $(16,22,30)$. However, serological criteria alone may not be sufficient for accurate tombusvirus classification because they 
were not always in agreement with results of nucleic acid hybridization studies and sequence analyses $(10,22)$. For example, it has been suggested that some serologically related tombusviruses described as distinctive species, e.g., Artichoke mottle crinkle virus (AMCV) and Carnation Italian ringspot virus (CIRV), should be considered strains of TBSV based on the high degree of sequence similarity with the TBSV-type strain $(27,30)$. On the other hand, serologically indistinguishable tombusviruses, e.g., Petunia asteroid mosaic virus (PAMV) (2) and TBSV-cherry strain, have been classified as identical tombusvirus species $(1,13$, $27)$ and also as strains of TBSV $(16,23)$.

We have determined the 3 '-end sequences of the genomes of several tombusvirus isolates obtained from lettuce, tomato, eggplant, and sugar beet (Beta vulgaris L.) and compared the serological properties of these isolates in order to better characterize tombusviruses associated with different crops and geographical regions. In this paper, we present evidence that a new tombusvirus is the causal agent of lettuce dieback disease and the new tomato greenhouse disease. We propose to name it Lettuce necrotic stunt virus (LNSV). The relationship of LNSV to other tombusvirus strains isolated from lettuce, tomato, sugar beet, and eggplant crops in California and the western part of the United States has been determined.

\section{MATERIALS AND METHODS}

Virus isolates and host range. Plant samples analyzed during this study were obtained from growers or were collected by our research group in 1996 to 1999. Samples of lettuce plants showing dieback symptoms were obtained from seven fields and one greenhouse in California in 1998 and from 18 fields in California and one field in Arizona in 1999. Lettuce plants showing localized leaf necrosis (but not the dieback symptoms) were collected from fields in Salinas, CA, in 1996 and 1997 and from one field in Chualar, CA, in 1998. Samples of tomato plants showing leaf curling, leaf chlorosis, and internal fruit necrosis were obtained from one greenhouse in Colorado in 1997 and 1998 and from one greenhouse in New Mexico in 1999 (48,49). Eggplants showing extensive leaf malformation were collected from one field in Fresno, CA, in 1999. All virus isolates originating from these samples are listed in Table 1. In addition, two TBSV isolates originating from the Imperial Valley in California are included in Table 1. Isolate SB1 was obtained by Liu et al. (25) from sugar beet showing vascular necrosis syndrome, and isolate T1 was obtained by Gerik et al. (11) from a tomato plant with tomato decline disease.

Leaf, root, or tomato fruit tissues were ground in $0.01 \mathrm{M}$ potassium phosphate buffer, $\mathrm{pH} 7.0$, containing $0.1 \%$ sodium sulfite and $1 \%$ celite, and resulting sap was rub-inoculated onto leaves of Nicotiana clevelandii, N. benthamiana, Gomphrena globosa, and Chenopodium quinoa plants. Plants were maintained in a greenhouse for up to 8 weeks, and were monitored weekly for symptoms. For plants developing disease symptoms, leaves were checked for the presence of virus particles by electron microscopy. Single local lesion isolates from C. quinoa plants were maintained on $N$. clevelandii plants. Standard tombusvirus isolates TBSVcherry (13) and Cucumber necrosis virus (CNV) (40) were provided by A. Jackson and D. A. Rochon, respectively, and maintained in $N$. clevelandii. Infection of indicator plants with an infectious clone of Cymbidium ringspot virus (CymRSV) was done by mechanical inoculation with in vitro-transcribed RNA from a full-length cDNA clone (7) and provided by T. Rubino.

Virus isolates were tested for their experimental host range by mechanical inoculation to different crop and ornamental plant species. The experimental host range of six virus isolates from lettuce (L1, L2, L3, L4, L6, and L7), and one isolate each from tomato (To2), eggplant (EP1), and sugar beet (SB1), respectively, was compared to the host range of CNV (32), TBSV-BS3 $(42,43)$, TBSV-T1 (11), and TBSV-cherry (PAMV) $(13,16)$.
Investigation of the soilborne nature of the diseases. Environmental growth chambers were used to conduct tests to determine the soilborne nature of lettuce dieback disease. Initially, 15 plants each of lettuce cvs. Darkland (susceptible romaine), New York (susceptible crisphead), and Imperial (resistant crisphead) were grown in soil obtained from fields infested with lettuce dieback pathogen from Chualar, CA. Plants were watered with a sterilized nutrient solution and maintained at 5,000 lx and $18^{\circ} \mathrm{C}$ with $12 \mathrm{~h}$ day. In pathogenicity tests, sap from $N$. clevelandii plants infected with the L2 or L7 isolate from lettuce or TBSV-cherry was prepared as described previously, and was poured onto sterilized soil containing 15 plants each of the same lettuce varieties listed above. Sap from $N$. clevelandii plants infected with the isolate To2 from tomato was poured onto sterilized soil containing 10 plants of tomato cv. Trust. These tomato plants were cultivated at 5,000 lx at $20^{\circ} \mathrm{C}$ with $12 \mathrm{~h}$ day. For a negative control, plant sap from healthy $N$. clevelandii plants was poured onto sterilized soil containing tomato or lettuce plants.

Electron microscopy. Leaf extracts were prepared for examination with the electron microscope by chopping tissue with a razor blade in $0.01 \mathrm{M}$ potassium phosphate buffer, $\mathrm{pH} 7.0$, at a ratio of approximately 1 part tissue to 5 parts buffer. One drop of extract was placed on a $0.4 \%$ Formvar-coated copper grid for $1 \mathrm{~min}$, followed by 20 drops of buffer and 20 drops of water. Grids were stained with $2 \%$ uranyl acetate containing bacitracin at $250 \mu \mathrm{g} / \mathrm{ml}$. Purified virus preparations were examined by placing $10 \mu \mathrm{l}$ (approximately $0.1 \mathrm{mg} / \mathrm{ml}$ ) on a grid followed by rinsing and staining as described previously.

Virus purification. Small- and large-scale virus purifications were performed according to Hillman et al. (14) using 0.5 and $10 \mathrm{~g}$ of infected leaf material, respectively. Extraction was performed in $0.2 \mathrm{M}$ sodium acetate, $\mathrm{pH} 5.2,0.1 \%$ 2-mercaptoethanol, followed by precipitation in $8 \%$ polyethylene glycol and $0.2 \mathrm{M}$ $\mathrm{NaCl}$. Virions were concentrated by low-speed centrifugation at $7,500 \times g$ for $20 \mathrm{~min}$ and resuspended in $100 \mu \mathrm{l}$ (small-scale) or $1 \mathrm{ml}$ (large-scale) of $0.01 \mathrm{M}$ sodium acetate, $\mathrm{pH} 5.5$, respectively. In the large-scale purification procedure, additional low-speed centrifugation and resuspension steps were included after the extraction in order to remove plant debris. A final high-speed centrifugation at $184,000 \times g$ for 90 min was used to recover virions, followed by resuspension of virus pellets by stirring overnight in $1 \mathrm{ml}$ of $0.01 \mathrm{M}$ sodium acetate, $\mathrm{pH}$ 5.5.

Western blot analysis. Tombusvirus isolate L1, isolated from lettuce with dieback disease, was used for antiserum production. Purified tombusvirus-L1 (LNSV) antigen in aliquots of $0.5 \mathrm{ml}$ each $\left(1.0 A_{260 \mathrm{~nm}}\right.$ units) was used for six intramuscular injections into a rabbit. Each aliquot was emulsified with $0.5 \mathrm{ml}$ of Freund's complete adjuvant (Becton Dickinson and Company, Franklin Lakes, NJ) just prior to injection. Injections were administered weekly, and bleedings were initiated 6 weeks after the first injection. Antisera produced against disrupted and whole particles of the TBSV-cherry strain were provided by A. Jackson, T. Rubio, and H. Scholthof.

Western blot procedure was conducted essentially as described by Tobwin et al. (45) with an electrophoresis cell and trans-blot electrophoretic transfer cell (Mini-PROTEAN II; Bio-Rad Laboratories, Hercules, CA) and 15\% sodium dodecyl sulfate (SDS) polyacrylamide gels according to manufacturer's instructions. Purified virus was quantified by UV spectrophotometry at $260 \mathrm{~nm}$ with an extinction coefficient of 5. Approximately $2.5 \mu \mathrm{g}$ of virus was loaded into each well, and amounts were checked and adjusted visually by Coomassie blue staining of protein gels. Purified virus extracted from plant tissues was either triturated in (i) an extraction buffer $(1: 2, \mathrm{vol} / \mathrm{vol})$ consisting of $75 \mathrm{mM}$ Tris- $\mathrm{HCl}$, $\mathrm{pH}$ 6.1, $9 \mathrm{M}$ urea, 7.5\% 2-mercaptoethanol, and 4.5\% SDS (41) when the TBSV-cherry strain antisera were used, or (ii) Laemmli extraction buffer $(1: 2, \mathrm{vol} / \mathrm{vol})$ consisting of $62.5 \mathrm{mM}$ Tris- $\mathrm{HCl}$, $\mathrm{pH}$ 6.8, 10\% glycerol, 5\% 2-mercaptoethanol, and 2\% SDS (24) 
when all other antisera were used. Samples were heated at $95^{\circ} \mathrm{C}$ for $5 \mathrm{~min}$ and centrifuged at $10,000 \times g$ for $2 \mathrm{~min}$. Extracted samples were stored at $4^{\circ} \mathrm{C}$. For western blot analyses, polyclonal antiserum prepared against disrupted particles of TBSV-cherry strain was diluted 1:8,000, and polyclonal antiserum against tombusvirus-L1 (LNSV) was diluted 1:500. Goat anti-rabbit immunoglobulin $\mathrm{G}$ alkaline phosphatase conjugate was diluted 1:2,000 (Sigma Chemical Co., St. Louis). TBSV and tombusvirus-L1 (LNSV) antisera were cross absorbed by incubation at $4^{\circ} \mathrm{C}$ overnight with sap from healthy plants. Healthy tissue was triturated with phosphate-buffered saline $(1: 100$, wt/vol), centrifuged for $10 \mathrm{~min}$ at $7,500 \times g$, and the supernatant was used for cross absorption.

Double-stranded RNA isolation. Fresh or frozen tissue of virus-infected $N$. clevelandii leaf tissue $(\approx 14 \mathrm{~g})$ was ground in liquid nitrogen with a mortar and pestle, and double-stranded (ds) RNA was isolated according to the method of Valverde et al. (47). Pellets were resuspended in $100 \mu \mathrm{l} 1 / 5$ strength STE buffer $(0.1 \mathrm{M}$

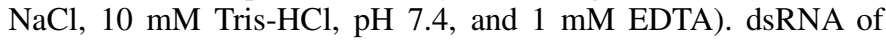
Tobacco necrosis virus (TNV) and standard TBSV strains were used as size markers. Analysis of dsRNA preparations $(5 \mu \mathrm{l})$ was performed in $1 \%$ agarose gels buffered with $40 \mathrm{mM}$ Tris-acetate, $\mathrm{pH}$ 8.3, $1 \mathrm{mM}$ EDTA, and $0.1 \mu \mathrm{g} / \mathrm{ml}$ ethidium bromide with fluorescent imaging at $254 \mathrm{~nm}$.

Reverse transcription-polymerase chain reaction. Total RNA (5 of $100 \mu$ lotal) isolated from $100 \mathrm{mg}$ of leaf tissue using RNAeasy RNA binding columns (Qiagen $\mathrm{GmbH}$, Hilden, Germany) or dsRNA ( $5 \mu \mathrm{l}$ ) was denatured by heating at $95^{\circ} \mathrm{C}$ for $10 \mathrm{~min}$ and annealed with an antisense oligonucleotide primer (3' TBSV: 5'-GGGCTGCATTTCTGCAAT-3'). First strand cDNA synthesis was performed in a $20-\mu$ l-reaction mixture using 200 units of Superscript II reverse transcriptase (RT) (Gibco BRL, Life Technologies Inc., Rockville, MD) according to the manufacturer's instructions. Single-stranded RNA was digested prior to polymerase chain reaction (PCR) amplification by incubation with $1 \mu \mathrm{l}$ of ribonuclease cocktail RNace-It (Stratagene, La Jolla, CA) at $37^{\circ} \mathrm{C}$ for $30 \mathrm{~min}$. Second strand synthesis and amplification of products were achieved by PCR using the antisense oligonucleotide primer paired with $5^{\prime}$ P22 or 5' P19 gene-specific oligonucleotide primers (5' P22: 5'-ATGGATACTGAATACGAA-3' and 5' P19: 5'-ATGGAACGAGCTATACAA-3'). According to alignments with tombusvirus sequences available in databases, the paired antisense and sense oligonucleotide primers were expected to specifically anneal to the genome of the TBSV-cherry (PAMV) isolate (EMBL M31019), TBSV-pepper isolate (EMBL U80935), TBSV-statice isolate (EMBL AJ249740), AMCV (EMBL X62493), CIRV (EMBL X85215), and CNV (EMBL M25270). Primers were designed and provided by A. Jackson and T. Rubio. PCR reactions were carried out with 1 unit of Taq DNA polymerase (Promega Corp., Madison, WI), $1 \times$ reaction buffer $(10 \mathrm{mM}$ Tris$\mathrm{HCl}, \mathrm{pH} 9.0,50 \mathrm{mM} \mathrm{KCl}$, and $0.1 \%$ Triton $\mathrm{X}-100), 2.5 \mathrm{mM}$ $\mathrm{MgCl}_{2}, 200 \mu \mathrm{M}$ each of dNTP, $25 \mathrm{pmol}$ each of primer, and $2 \mu \mathrm{l}$ of cDNA template in a final volume of $50 \mu$. The reaction mixture was heated to $94^{\circ} \mathrm{C}$ for $3 \mathrm{~min}$, submitted to 35 cycles at $94^{\circ} \mathrm{C}$ for 1 $\min , 56^{\circ} \mathrm{C}$ for $2 \mathrm{~min}, 72^{\circ} \mathrm{C}$ for $3 \mathrm{~min}$, and finally heated to $72^{\circ} \mathrm{C}$ for $10 \mathrm{~min}$.

Cloning of PCR products and sequence analysis. RT-PCRamplified DNA fragments were cloned into the TA-cloning vectors pCR2.1 (Invitrogen, Carlsbad, CA) or pGEM-T Easy (Promega) according to the manufacturer's instructions. Recombinant plasmids containing cloned cDNAs were purified with a plasmid kit according to the manufacturer's instructions (Qiagen). Cloned DNA fragments in recombinant plasmids and PCR-amplified DNA fragments were sequenced on both strands at the University of Florida Interdisciplinary Center for Biotechnology Research DNA Sequencing Core Laboratory (Gainesville) using universal M13-forward and M13-reverse primers and virus-specific primers synthesized by Gibco BRL. Nucleotide and deduced amino acid sequence analyses were aligned and pairwise distance matrixes calculated with the programs PileUp and GrowTree of the Genetics Computer Group Inc., Wisconsin Package, version 10.0 (Madison). Phylogenetic trees were calculated according to the Neighbor joining method after exclusion of positions with gaps and correction for multiple substitutions by the Kimura parameter using the program ClustalX 1.8 (44). Bootstrap analysis was performed for 100 trials using the same program. Graphical representation of the tree was done using the program NJPlot (37). EMBL database accession numbers of the sequences generated in this study are as follows: LNSV-L1 (AJ288915), LNSV-L2 (AJ288916), TBSV-L3 (AJ288917), LNSV-L4 (AJ288918), CNV-L4 (AJ288919), CNVL5 (AJ288920), CNV-L6 (AJ288921), CNV-L7 (AJ288922), TBSV-L8A (AJ288923), TBSV-L8B (AJ288924), TBSV-L8C

TABLE 1. Characteristics of tombusvirus isolates examined in this study

\begin{tabular}{|c|c|c|c|c|c|c|}
\hline \multirow{2}{*}{$\begin{array}{l}\text { Isolate } \\
\text { name }\end{array}$} & \multirow{2}{*}{$\begin{array}{l}\text { Original } \\
\text { host plant }\end{array}$} & \multirow{2}{*}{$\begin{array}{l}\text { Symptoms of host plants } \\
\text { (tissue used for inoculation) }\end{array}$} & \multirow[b]{2}{*}{ Geographic origin, year of sampling } & \multicolumn{2}{|c|}{$\begin{array}{l}\text { Western blot reaction } \\
\text { with antisera for }{ }^{\mathrm{a}}\end{array}$} & \multirow{2}{*}{$\begin{array}{c}\text { Virus species } \\
\text { according to genome } \\
\text { sequence composition }\end{array}$} \\
\hline & & & & TBSV-cherry & LNSV & \\
\hline L1 & Lettuce & Leaf chlorosis, necrosis, stunting, dieback (leaf) & Salinas, CA, mid-1980s & $(+)$ & + & LNSV \\
\hline $\mathrm{L} 2$ & Lettuce & Leaf chlorosis, necrosis, stunting, dieback (leaf) & Salinas, CA, 1997, organic field & $(+)$ & + & LNSV \\
\hline L3 & Lettuce & Leaf chlorosis, necrosis, stunting, dieback (leaf) & Gonzales, CA, 1998 & + & - & TBSV-cherry \\
\hline L4 & Lettuce & Leaf chlorosis, necrosis, stunting, dieback (leaf) & Chualar, CA, 1998, same field as L9 & $(+)$ & + & LNSV and CNV \\
\hline L5 & Lettuce & Localized leaf necrosis, root necrosis (root) & Salinas, CA, 1997, organic field & $(+)$ & - & $\mathrm{CNV}$ \\
\hline L6 & Lettuce & Localized leaf necrosis (leaf) & Chualar, CA, 1998 & $(+)$ & - & CNV \\
\hline L7 & Lettuce & Localized leaf necrosis (leaf) & Salinas, CA, 1996 & $(+)$ & - & CNV \\
\hline L8 & Lettuce & Leaf chlorosis, necrosis, stunting, dieback (leaf) & Yuma, AZ, 1999 & + & - & TBSV-cherry \\
\hline L9 & Lettuce & Leaf chlorosis, necrosis, stunting, dieback (leaf) & Chualar, CA, 1998, same field as L4 & $(+)$ & + & LNSV \\
\hline To1 & Tomato & $\begin{array}{l}\text { Leaf chlorosis, internal fruit necrosis } \\
\text { (inflorescence) }\end{array}$ & CO, 1998, greenhouse & n.t. & n.t. & LNSV and CNV \\
\hline To2 & Tomato & Leaf chlorosis, internal fruit necrosis (fruit) & CO, 1997, greenhouse & $(+)$ & - & LNSV \\
\hline To3 & Tomato & $\begin{array}{l}\text { Leaf chlorosis, internal fruit necrosis } \\
\text { (inflorescence) }\end{array}$ & NM, 1999, same greenhouse as To4 & $(+)$ & + & LNSV \\
\hline To4 & Tomato & Leaf chlorosis, internal fruit necrosis (fruit) & NM, 1999, same greenhouse as To3 & + & - & TBSV-cherry \\
\hline T1 & Tomato & Leaf chlorosis, tomato plant decline (root) & Imperial Valley, CA, 1986 & + & - & $\begin{array}{l}\text { TBSV-cherry and } \\
\text { TBSV-BS3 }\end{array}$ \\
\hline SB1 & Sugar beet & Root necrosis, vascular necrosis syndrome (root) & Imperial Valley, CA, 1994 & + & - & LNSV \\
\hline EP1 & Eggplant & Leaf malformation (leaf) & Fresno, CA, 1999 & + & - & TBSV-cherry \\
\hline
\end{tabular}

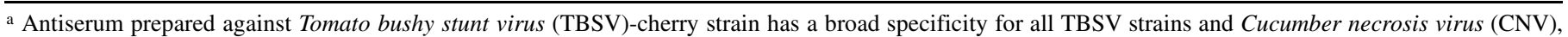
whereas antiserum prepared against the tombusvirus isolate L1 from Lettuce necrotic stunt virus (LNSV) is highly specific. + Indicates reaction with $41-\mathrm{kDa}$ protein (coat protein); (+) indicates weak reaction with 41-kDa protein; - indicates no reaction; and n.t. indicates not tested.

b Based on sequence analyses of single clones obtained from 829 to 847 bp of the 3' end of viral RNAs starting with the P19 gene. 


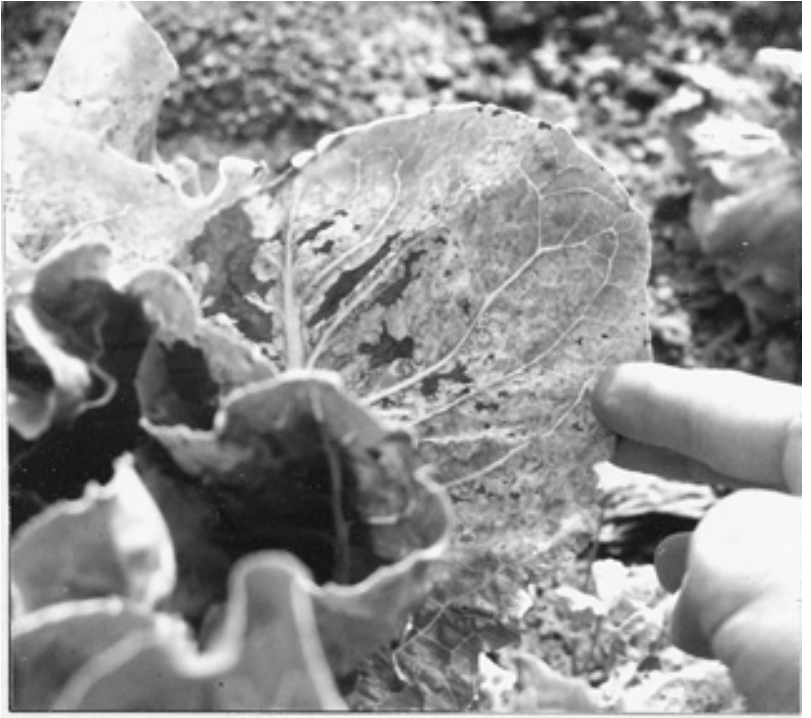

A

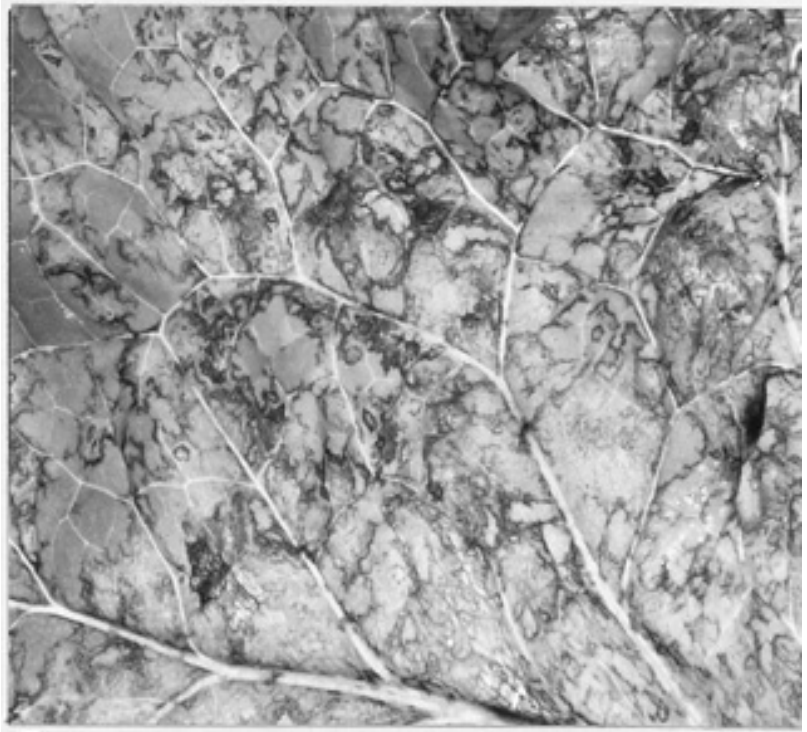

B

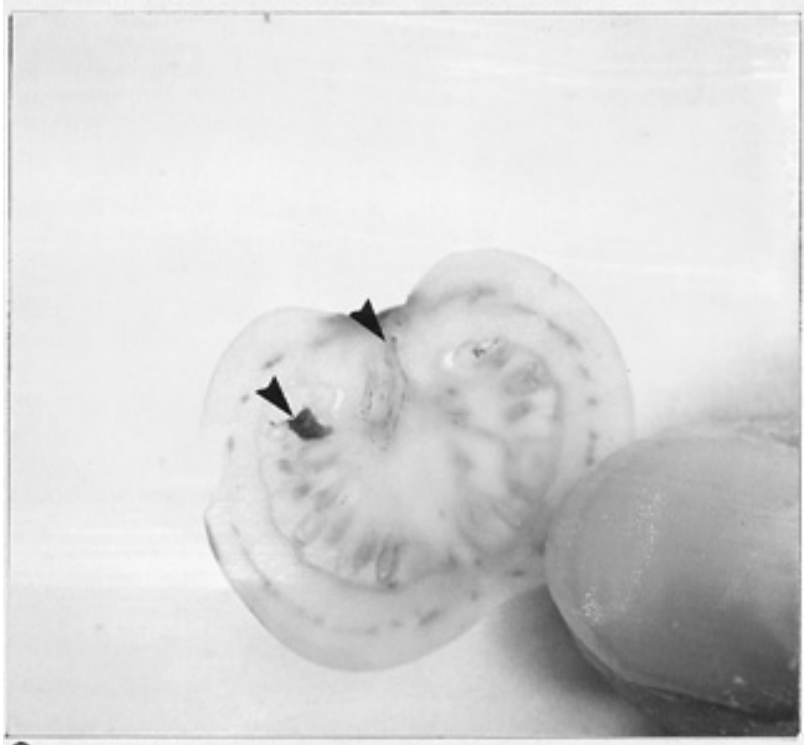

C

Fig. 1. Leaves of A, romaine and $\mathbf{B}$, crisphead lettuce showing typical symptoms of lettuce dieback disease. C, Tomato fruit showing internal browning and necrosis typical of a new tomato greenhouse disease. Arrows indicate necrotic tissue.
(AJ288925), TBSV-To1 (AJ288926), CNV-To1 (AJ288927) LNSV-To2 (AJ288928), LNV-To3A (AJ288929), LNSV-To3B (AJ288930), LNSV-To3C (AJ288931), LNSV-To3D (AJ288932), LNSV-To3E (AJ288933) LNSV-To3F (AJ288934), LNSV-To3G (AJ288935), LNV-To3J (AJ288936), LNSV-To3K (AJ288937), LNSV-To3L (AJ288938), LNSV-To3M (AJ288939), LNSV-To4A (AJ288940), TBSV-To4B (AJ288941), TBSV-To4C (AJ288942), TBSV-T1 (AJ288943), LNSV-SB1 (AJ288944), and TBSV-EP1 (AJ288945).

\section{RESULTS}

Origin of samples and disease symptoms. Diseased plants showed two different types of symptoms. Plants from fields with lettuce dieback disease were stunted and showed extensive necrosis and yellowing on the leaves (Fig. 1A). Some varieties also developed necrotic ring spot patterns on the leaves (Fig. 1B). Roots were not necrotic. In other fields, lettuce plants were found sporadically that showed localized necrosis on older leaves, which sometimes was accompanied by extensive root necrosis. Tomato plants received from greenhouses in Colorado and New Mexico showed chlorosis and necrotic speckling of the leaves, leaf curling, chlorosis of inflorescences, and internal necrosis of the fruit (Fig. 1C). Eggplants sampled in Fresno, CA, had malformed leaves.

Host range. All the virus isolates tested had a wide host range that was identical to the host range of all tested strains of TBSV and CNV (Table 2). Of the 40 plant species tested, 32 species from 9 plant families developed symptoms after inoculation with the isolates. C. quinoa leaves inoculated with sap from leaves from dieback-affected lettuce plants developed necrotic local lesions in 5 to 7 days. All tombusvirus-lettuce isolates elicited necrotic local lesions on the inoculated leaves when lettuce plants were mechanically inoculated with sap from virus-infected $N$. clevelandii plants, but did not induce the typical dieback symptoms.

Soilborne nature of lettuce and tomato diseases and pathogenicity of virus isolates. Lettuce dieback disease developed in lettuce plants grown in soil collected from infested fields. Typical dieback symptoms also developed in lettuce seedlings grown in sterile soil amended with sap of the tombusvirus-L2 isolate. Thirtythree days after addition of the sap to the soil, typical dieback symptoms, including necrotic ring spots, developed in 5 of 15 plants (experiment 1) and 3 of 15 plants (experiment 2) of susceptible cv. Darkland, 3 of 15 plants (each of 2 experiments) of susceptible 'New York', and none of the plants of resistant 'Imperial'. Symptoms similar to typical dieback, including yellowing of the leaves, developed when lettuce seedlings (4 of 15) of cv. Darkland were grown in sterile soil amended with the TBSV-cherry isolate.

Back-inoculation of indicator plants (C. quinoa, N. benthamiana, and $N$. clevelandii) with sap from leaf tissue from the soilinoculated symptomatic lettuce plants resulted in symptoms indistinguishable from those of the original virus isolate (L2). No plants grown in sterile soil amended with sap from virus-free $N$. clevelandii plants or in sterile soil amended with sap of L7 developed symptoms.

Leaf chlorosis, curling, and necrotic specks developed in tomato plants grown in sterile soil amended with sap prepared from To2infected $N$. clevelandii plants. Thirty-six days after addition of sap to the soil, symptoms including necrosis of leaves and flowers developed on 3 of 10 plants. Inoculation of indicator plants $(C$. quinoa, $N$. benthamiana, and $N$. clevelandii) with sap from soilinoculated symptomatic tomato plants resulted in symptoms indistinguishable from those induced by the original virus isolate. No plants grown in sterile soil amended with sap from virus-free $N$. clevelandii plants developed symptoms.

Structure and physicochemical properties. Electron microscopy. Virus particles were not observed in plant sap prepared 
from field-collected lettuce plants with dieback symptoms. However, spherical virus particles measuring $30 \mathrm{~nm}$ in diameter (Fig. 2) were detected consistently in sap of symptomatic leaves from indicator plants ( $C$. quinoa, $N$. benthamiana, and $N$. clevelandii) that had been rub-inoculated with sap prepared from root and leaf tissue of dieback-affected lettuce plants or from lettuce plants with root necrosis and localized necrosis on the older leaves. No such virus-like particles were detected in indicator plants inoculated with asymptomatic lettuce samples. Virus particles measuring $30 \mathrm{~nm}$ in diameter were also detected in sap of symptomatic indicator plants that had been rub-inoculated with sap prepared from inflorescence or fruit tissue of greenhouse-grown tomatoes, with necrotic inflorescence tissue, with fruit tissue showing internal necrosis and from indicator plants that had been rubinoculated with sap prepared from field-grown eggplant with malformed leaf tissue.

Serology. SDS-polyacrylamide gel electrophoresis of purified virus preparations revealed a viral coat protein of approximately $41 \mathrm{kDa}$ for virus isolates from lettuce and tomato (data not shown). In western blot analyses, an antiserum prepared against disrupted particles of the TBSV-cherry strain reacted with the $41-\mathrm{kDa}$ proteins from TBSV-cherry, TBSV-BS3, and CNV-cucumber (Fig. $3 \mathrm{~A}$ ). Isolates from lettuce, tomato, beet, and eggplant also reacted with this antiserum, although some reactions were weak (Fig. 3A; Table 1). Virus isolates L3 and L8 had a close serological relationship to the TBSV-cherry strain based on a strong reaction with the TBSV-cherry antiserum. Isolates from sugar beet and eggplant also reacted strongly with the TBSV-cherry antiserum. Virus isolates L1, L2, L4, L5, L6, and L7 reacted weakly with this antiserum, suggesting a more distant serological relationship with the TBSV-cherry strain. Antiserum prepared against the tombusvirusL1 isolate from dieback-affected lettuce did not react in western blots with standard TBSV strains, but was highly specific for the L1, L2, L4, L9, and To3 isolates (Fig. 3B; Table 1).

dsRNA analysis. The major dsRNA bands from $N$. clevelandii plants that developed symptoms after inoculation with sap from dieback-affected lettuce leaves or from necrotic tomato fruits were similar to those obtained from TBSV- and CNV-infected $N$. clevelandii (Fig. 4). The dsRNA bands from $N$. clevelandii plants infected with TNV were distinct from those of TBSV, CNV, and the lettuce and tomato isolates (Fig. 4). Isolate To1, which induced attenuated symptoms had one small dsRNA band in addition to the three major genomic and subgenomic dsRNA bands (Fig. 4).

Phylogenetic relationships based on nucleotide sequence analysis. A region at the $3^{\prime}$ end of the genomic RNA corresponding to nucleotides 3888 to 4733 of the TBSV-cherry strain was

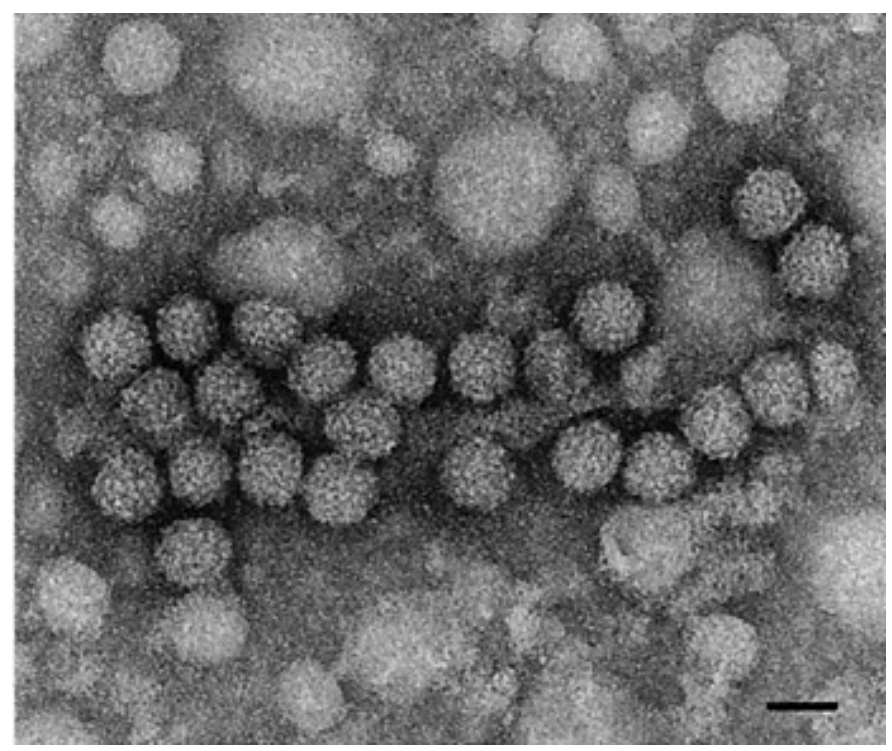

Fig. 2. Electron micrograph of isometric viral particles in an extract from Chenopodium quinoa leaves from a plant infected after mechanical inoculation with sap from dieback-affected lettuce leaves. Grids were negatively stained with $2 \%$ uranyl acetate. The bar represents $30 \mathrm{~nm}$.

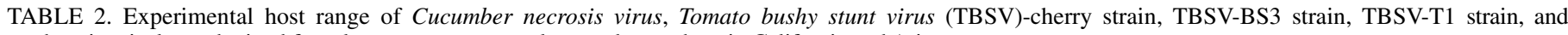
tombusvirus isolates obtained from lettuce, tomato, eggplant, and sugar beet in California and Arizona ${ }^{\mathrm{a}}$

\begin{tabular}{|c|c|c|c|c|c|}
\hline Host & Local & Systemic & Host & Local & Systemic \\
\hline Amaranthaceae & & & Geraniaceae & & \\
\hline Gomphrena globosa & NL & $\ldots$ & Geranium hybrida & $\ldots$ & $\ldots$ \\
\hline Apiaceae & & & Graminaceae & & \\
\hline Apium graveolens & $\ldots$ & $\ldots$ & Avena sativa & $\ldots$ & $\ldots$ \\
\hline Daucus carota & $\ldots$ & $\ldots$ & Leguminose & & \\
\hline Brassicaceae & & & Pisum sativum & NL & NL \\
\hline Arabidopsis thaliana ${ }^{\mathrm{b}}$ & CL & CL & Malvaceae & & \\
\hline Brassicae oleraceae & $\ldots$ & $\ldots$ & Gossypium hirsutum & NS & $\ldots$ \\
\hline Capsella bursa-pastoris & $\ldots$ & $\ldots$ & Malva parviflora & NL, CL & NL, CL \\
\hline Caryophyllaceae & & & Rosaceae & & \\
\hline Dianthus caryophyllus & $\ldots$ & $\ldots$ & Fragaria $\times$ ananassa & CL & CL \\
\hline Chenopodiaceae & & & Solanaceae & & \\
\hline Beta vulgaris & $\mathrm{NS}, \mathrm{NL}$ & $\ldots$ & Capsicum annuum & CL, NR & CL, NR \\
\hline Chenopodium amaranthicolor & NL & $\ldots$ & Datura stramonium & $\mathrm{NL}, \mathrm{CL}$ & NL, CL \\
\hline Chenopodium capitatum & NL & $\ldots$ & Lycopersicon esculentum & CL & CL \\
\hline Chenopodium murale & NL & $\ldots$ & Lycopersicon pimpinellifolium & $\mathrm{NS}, \mathrm{CL}$ & NL, CL \\
\hline Chenopodium quinoa & NL & NL, SN, PD & Nicotiana clevelandii & NL & NL, Mo, LD, PD \\
\hline Spinacia oleracea & NS & NS, LD, PD & Nicotiana benthamiana & CS & Mo, W, PD \\
\hline Compositae & & & Nicotiana glauca & CS & $\ldots$ \\
\hline Cichorium intybus & NL & $\ldots$ & Nicotiana glutinosa & NL & $\ldots$ \\
\hline Cynara cardununculus & $\ldots$ & $\ldots$ & Petunia hybrida & $\mathrm{NL}, \mathrm{CL}$ & $\ldots$ \\
\hline Cynara scolymus & CL & $\ldots$ & Physalis alkegen & NL & $\ldots$ \\
\hline Lactuca sativa & NL & $\ldots$ & Physalis floridana & NL, CL & $\ldots$ \\
\hline Sonchus oleraceus & NL & $\ldots$ & Physalis wrightii & NL & $\ldots$ \\
\hline Cucurbitaceae & & & Solanum melongena & CL & CL \\
\hline Citrullus lanatus & NS & $\ldots$ & & & \\
\hline Cucumber sativus & NL & $\ldots$ & & & \\
\hline Cucumis melo & NL & $\ldots$ & & & \\
\hline
\end{tabular}

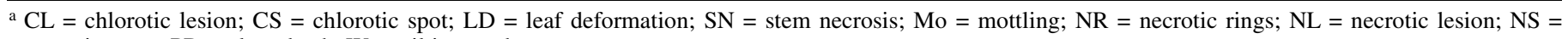
necrotic spots; $\mathrm{PD}=$ plant death; $\mathrm{W}=$ wilting; and $\ldots=$ no symptoms.

${ }^{\mathrm{b}}$ Ecotype Columbia. 
amplified by RT-PCR and cloned from dsRNA or total RNA preparations of isolates from lettuce, tomato, sugar beet, and eggplant. The nucleotide sequences of these clones were determined and used to determine the phylogenetic relationship of these isolates with previously described tombusviruses. These sequences included the complete coding region for the P19 protein and most of the $3^{\prime}$-terminal untranslated region (UTR; excluding the $3^{\prime}$ terminal $43 \mathrm{bp}$ of the TBSV-cherry strain). The $3^{\prime}$-terminal UTR and the deduced amino acid sequences of the P19 proteins were used to determine the phylogenetic relationships among these virus isolates (Table 3 ). The nucleotide and the amino acid sequences of the P19 gene and protein, respectively, were more conserved than the nucleotide sequence of the $3^{\prime}$-terminal UTR. The 3 -terminal nucleotide sequence used in the phylogenetic analysis ( 829 to $847 \mathrm{bp}$ ) included the 519-bp P19 coding region and the 310- to 328-bp 3'-terminal UTR.

A phylogenetic tree based on the genetic distance data for the 3 -terminal nucleotide sequence is presented in Figure 5. The grouping presented in the right column is based on biological and serological data $(10,22,23,29,30)$ for comparison with the group-

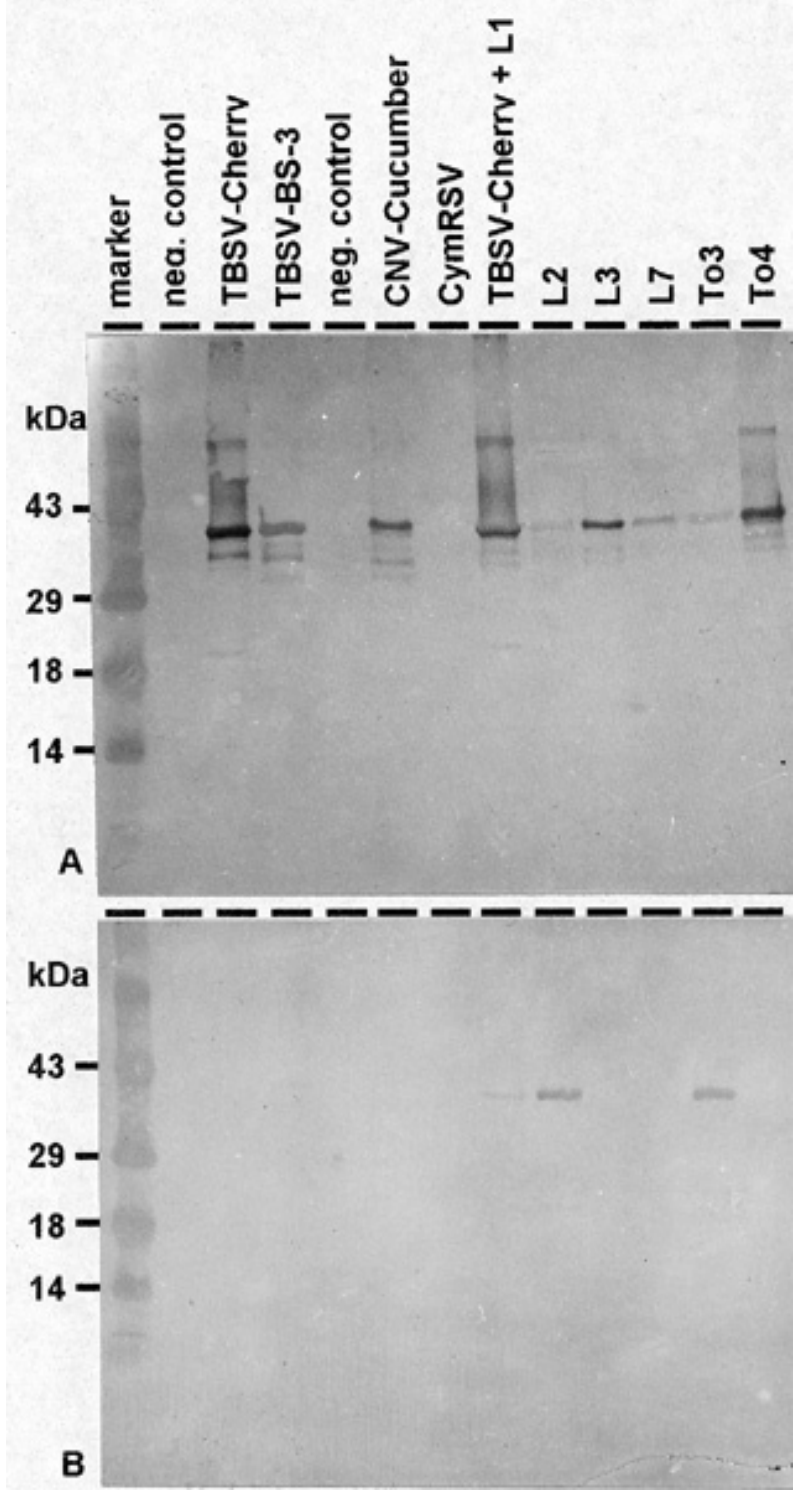

Fig. 3. Western blot analysis of purified virus preparations of standard tombusvirus isolates (cherry and BS3 strain of Tomato bushy stunt virus [TBSV], Cymbidium ringspot virus [CymRSV], and Cucumber necrosis virus [CNV-cucumber]), and virus isolates originating from lettuce (L2, L3, and L7) and tomato (To3 and To4) using antisera prepared against A, TBSVcherry and $\mathbf{B}$, tombusvirus-L1 from lettuce (LNSV). ing based on the phylogenetic tree on the left. Two major serologically distinct TBSV groups have been described previously $(22,30)$ : the TBSV-cherry strain and the TBSV-type/BS3 strain group (the BS3 strain was obtained after repeated passages of the TBSV tomato-type strain [43]).

Although TBSV-cherry (PAMV), TBSV-BS3, and CIRV can be distinguished based on their serological properties, they form one cluster based on analyses of the $3^{\prime}$-terminal sequence (P19 gene plus 3 '-UTR) (Fig. 5). In contrast, the tombusvirus isolates L1, L2, and L4 from lettuce, To2 and To3 from tomato, and SB1 from sugar beet formed a single cluster that is clearly distinct (bootstrap value of 100) from clusters of other tombusvirus species and strains, including all TBSV isolates, CIRV, AMCV, CNV, and CymRSV.

Because most isolates (e.g., L1, L2, and L4) forming this new cluster were obtained from lettuce with dieback symptoms, this group is provisionally referred to as the LNSV group. The $3^{\prime}$ terminal nucleotide sequence composition of isolates in this group is 12.2 to $17.1 \%$ different from 3 '-terminal sequences of previously described TBSV strains or isolates (e.g., $12.8 \%$ sequence divergence between TBSV-type and LNSV-L2 and $16.9 \%$ between TBSV-BS3 and LNSV-L4) (Table 3). The divergence within 3'-terminal sequences of previously described TBSV strain isolates extends from $0.6 \%$ (TBSV-BS3 to TBSV-type) to $7.7 \%$ (TBSV-cherry to TBSV-type). Thus, the maximal sequence divergence within TBSV strain groups is approximately half of the sequence divergence between TBSV strains and isolates from the LNSV group. However, the 3'-terminal sequences of the LNSV group isolates are more closely related to those of TBSV strains than to those of CNV (23.4 to $24.8 \%$ sequence divergence) (Table 3).

The L3 and L8 isolates from lettuce with dieback symptoms were most closely related to the cherry strain of TBSV (PAMV, 0.1 to $0.6 \%$ sequence divergence). Isolates from lettuce plants without dieback symptoms, but with extensive root necrosis and localized necrotic lesions on older leaves (L5, L6, and L7), were

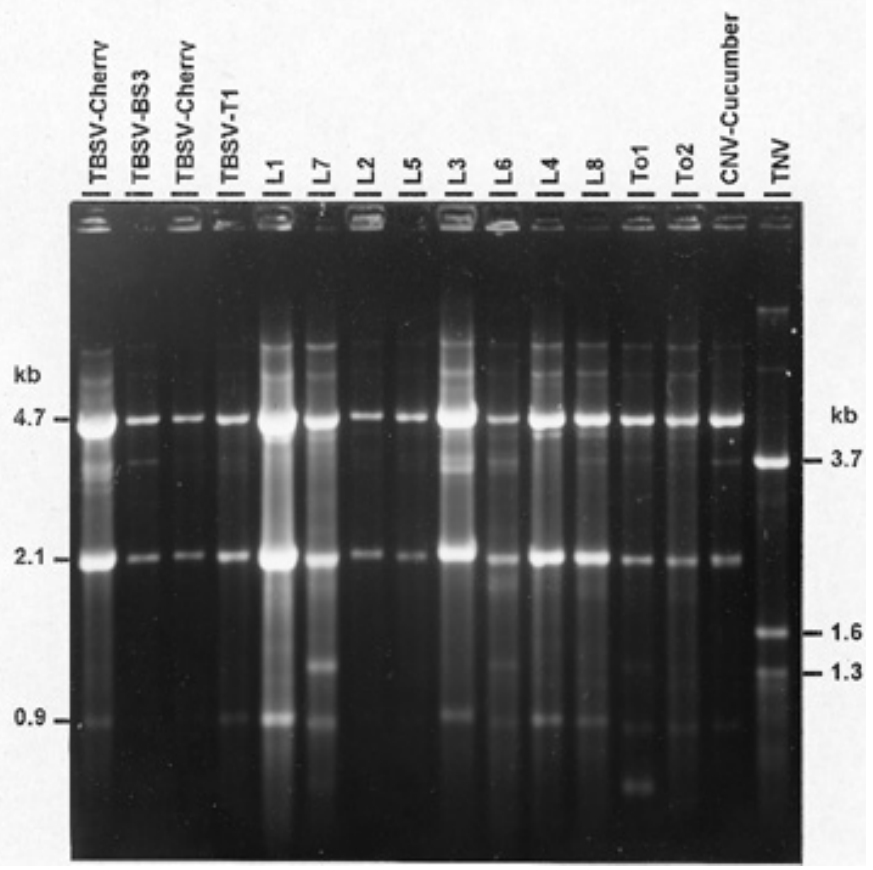

Fig. 4. Double-stranded RNAs of tombusvirus isolates from lettuce (L1 through L8) and tomato (To1 and To2) compared with those from Tomato bushy stunt virus (TBSV-cherry, TBSV-BS3, and TBSV-T1), Cucumber necrosis virus (CNV-cucumber), and Tobacco necrosis virus (TNV) isolates. Sizes of genomic and subgenomic double-stranded RNAs for standard tombusvirus isolates are indicated on the left and for TNV on the right. 
more closely related to the CNV-type isolate from cucumber ( 4.8 to $5.1 \%$ sequence divergence) than to TBSV (21.8 to $25.6 \%$ sequence divergence). Sequence analyses of individual clones derived from a dsRNA preparation of isolate L4 indicated that it contained a mixture of two clones (Table 3; Fig. 5). One of these formed a new cluster different from other tombusviruses (LNSVL4) and the other one clustered with CNV-type (CNV-L4).

Several clones of the 3 -terminal nucleotide sequence from one tomato isolate (LNSV-To3) were sequenced to evaluate the genetic diversity of an isolate (data not shown). Four of the eleven clones were identical; the largest sequence divergence among all 11 sequences was $0.8 \%$. Three clones of another isolate (TBSVTo4) from tomato showed $0.4 \%$ maximum sequence divergence, and three clones from a lettuce isolate (TBSV-L8) showed $0.7 \%$ maximum sequence divergence. All sequences obtained from isolate To3 clustered with the new LNSV group, whereas all sequences from To4 and L8 isolates clustered with the TBSVcherry group. These results indicate that, for these tombusvirus isolates from tomato and lettuce, plants were infected with minor sequence variants of a single tombusvirus rather than mixed infections of several distinct tombusvirus species or strains, such as L4. Therefore, consensus sequences for the LNSV-To3, TBSVTo4, and TBSV-L8 isolates were used to calculate the distance matrix and the phylogenetic relationships shown in Figure 5.

Sequence comparisons of the 3 '-terminal nucleotide sequences of virus isolates obtained from dieback-affected lettuce and with those of isolates from other crops correlated well with most of the results obtained by western blot analysis (Table 2). However, sequence analyses of several clones provided evidence for mixed infections with CNV, TBSV-cherry, or TBSV-BS3 (Table 2) (e.g., isolates L4 and T1) that were not revealed by western blot analyses.

\section{DISCUSSION}

Based on the results presented above, we conclude that the recently observed dieback disease of lettuce in California and Arizona is caused by a previously undescribed tombusvirus. We propose to name this new tombusvirus LNSV. This virus was also associated with a new disease of greenhouse-grown tomatoes in Colorado and New Mexico.

The taxonomy of the genus Tombusvirus has been based mainly on serology and host range (29). However, we were unable to differentiate TBSV and CNV standard isolates and virus isolates obtained from lettuce, tomato, sugar beet, and eggplant based on host range. Small differences in symptom severity and the efficiency of systemic invasion were not sufficiently reliable to differentiate these isolates. In addition, all virus isolates exhibited similar dsRNA patterns typical for tombusviruses. However, western blot analyses revealed that tombusviruses isolated from lettuce were serologically distinct from previously described tombusviruses and TBSV strains, but were serologically related to some tombusviruses isolated from diseased greenhouse-grown tomatoes in Colorado and New Mexico.

These TBSV-related viruses were recovered consistently from lettuce plants with dieback symptoms that showed leaf chlorosis

TABLE 3. Estimated percent pairwise genetic identities among tombusvirus 3 '-terminal genomic nucleotide sequences and P19 protein amino acid sequences ${ }^{\text {a }}$

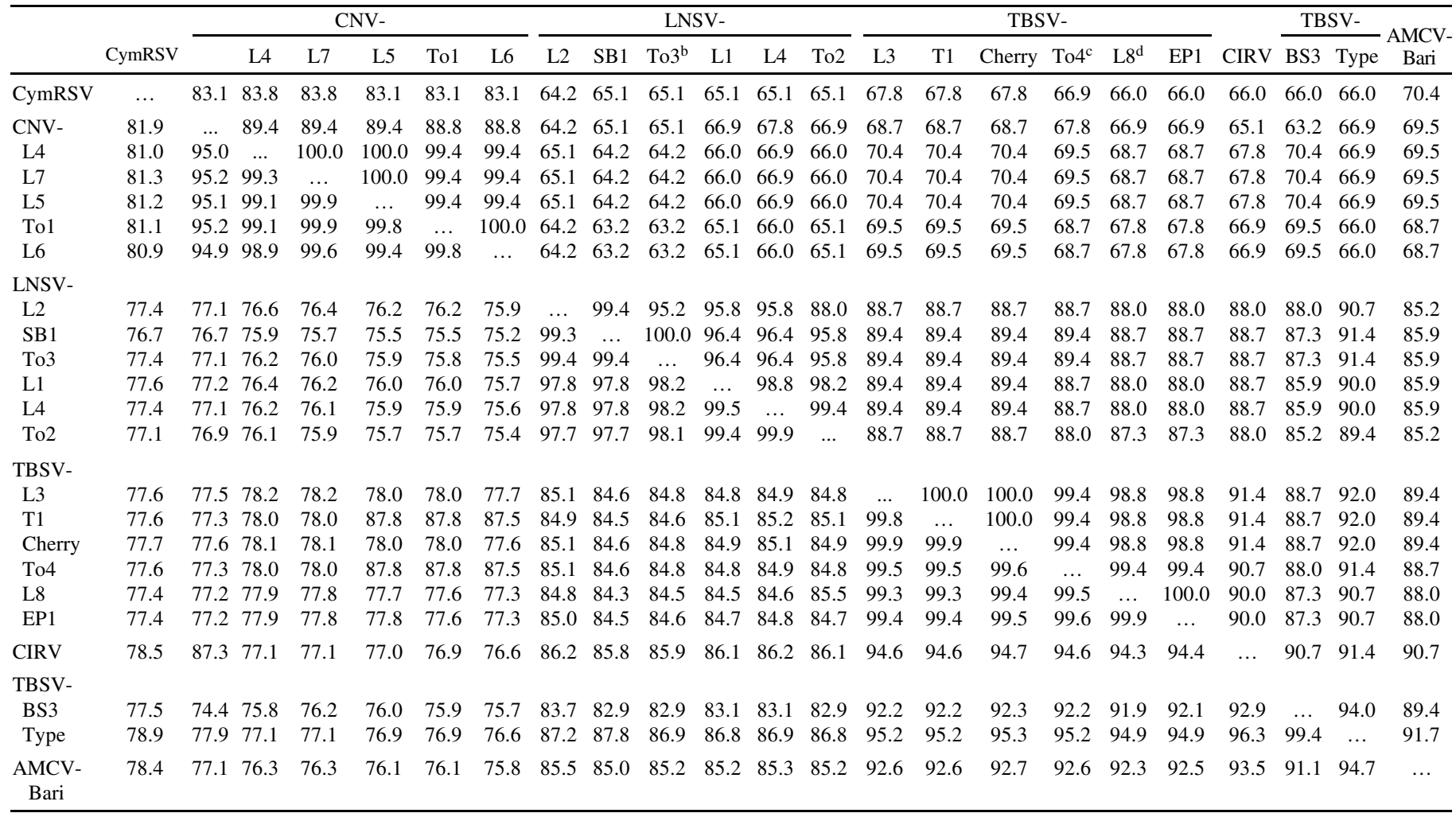

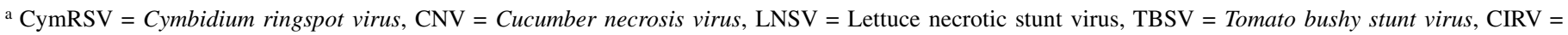
Carnation Italian ringspot virus, and AMCV-Bari = Artichoke mottle crinkle virus and tombusvirus isolates obtained from lettuce (L1, L2, L3, L4, L6, L7, and L8), tomato (To1, To2, To3, and To4), eggplant (EP1), and sugar beet (SB1). The matrix was calculated using the program GrowTree of the Genetics Computer Group, Wisconsin Package, version 10.0 (Madison). Pairwise identity values for comparisons with sequences obtained from databases are CymRSV, CNV, TBSV-Cherry, CIRV, TBSV-BS3, TBSV-Type, and AMCV-Bari, and all other data in plain text. Below the diagonal: 829- to 847-bp nucleotide sequence

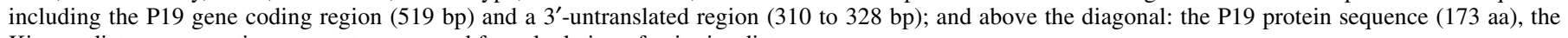
Kimura distance correction parameter was used for calculation of pairwise distances.

b Consensus sequence from three clones.

c Consensus sequence from 11 clones.

${ }^{\mathrm{d}}$ Consensus sequence from three clones. 
and necrosis, whereas a virus closely related to CNV was consistently isolated from lettuce plants with root necrosis and localized leaf necrosis. However, from 1 of 18 lettuce fields, a mixture of a TBSV- and a CNV-related virus was recovered from a single lettuce plant with dieback symptoms.

Partial sequences are available for several tombusvirus isolates, which have been useful in classification and strain differentiation of tombusvirus isolates (27). We used primers specific for the $3^{\prime}$ terminus of tombusvirus genomes for cloning of parts of the genomic RNA for two reasons: (i) the availability of substantial sequence data from this region for isolates from different crops; and (ii) the region is highly conserved among tombusviruses, and primers used in RT-PCR permitted detection of a wide range of TBSV-related viruses including previously uncharacterized isolates.

Phylogenetic analyses of the 3 '-terminal sequences of tombusvirus isolates from lettuce and tomato revealed two distinct groups. One group was closely related to the previously described TBSV-cherry strain group (PAMV), whereas the other was a new group that was more distantly related to the TBSV-cherry (14.4 to

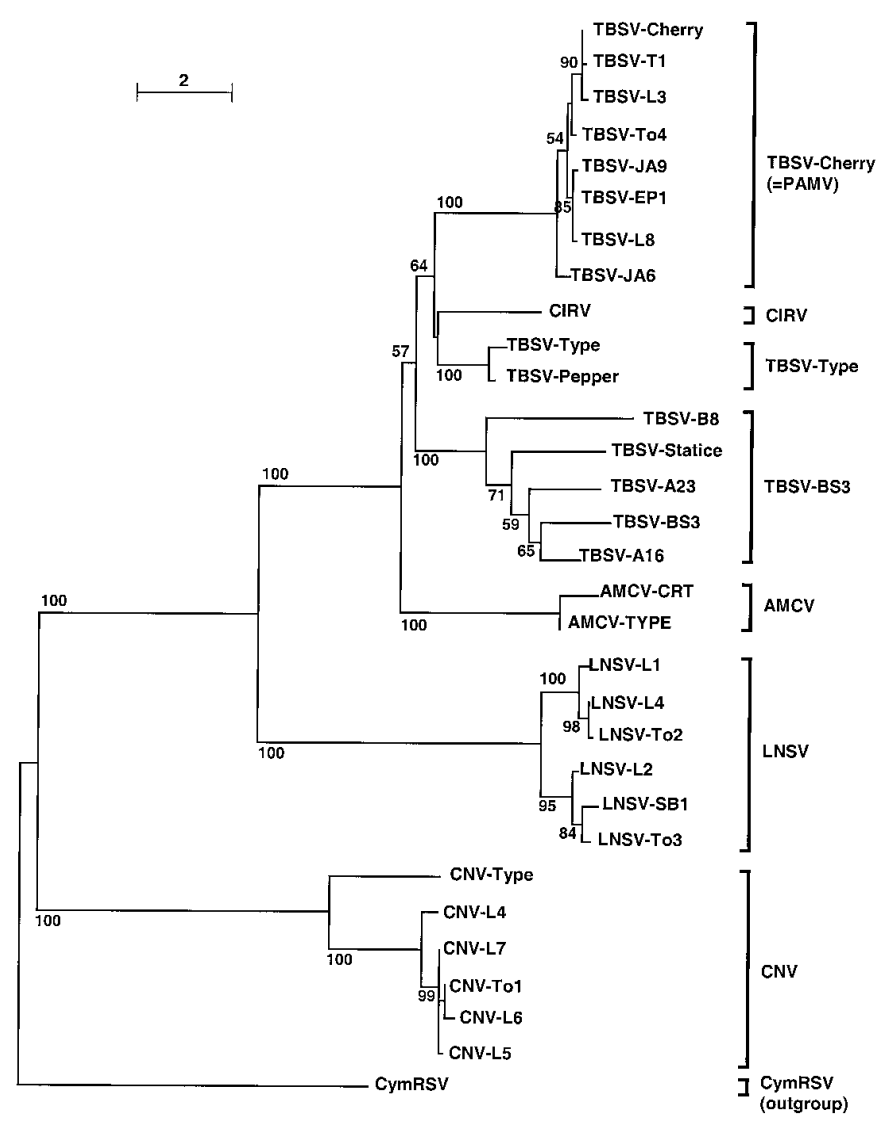

Fig. 5. Phylogenetic relationship of tombusviruses obtained from lettuce, tomato, eggplant, and sugar beet based upon analysis of terminal $3^{\prime}$-genomic nucleotide sequences (829 to $847 \mathrm{bp}$ of the $3^{\prime}$-terminus starting with the P19 gene). Values at nodes indicate bootstrap values $(>50 \%)$ based upon 100 replicates. The bar represents the estimated percent sequence divergence. Tombusvirus isolates (Tomato bushy stunt virus (TBSV), Petunia asteroid mosaic virus (PAMV), Carnation Italian ringspot virus (CIRV), Artichoke mottled crinkle virus (AMCV), Cymbidium ringspot virus (CymRSV), and Cucumber necrosis virus (CNV) are grouped together on the right according to biological and serological differences. Some isolates obtained from lettuce plants with dieback symptoms (LNSV-L1, LNSV-L2, and LNSV-L4) cluster together in a new group (Lettuce necrotic stunt virus [LNSV]). One isolate from a lettuce plant with dieback symptoms (TBSV-L3) clustered together in a group with the TBSV-cherry strain (synonymous with PAMV). Isolates obtained from plants with symptoms differing from lettuce dieback disease (CNV-L4, CNV-L5, CNV-L6, and CNV-L7) cluster together in a group with the CNV-type isolate from cucumber.
$15.5 \%$ sequence divergence), TBSV-type (12.2 to $13.2 \%$ sequence divergence), and TBSV-BS3 (16.3 to $17.1 \%$ sequence divergence) strain groups and to $\mathrm{CNV}$ (32.2 to $36.8 \%$ sequence divergence). In contrast, the maximum sequence divergence within TBSV strain groups was $7.7 \%$. In addition, based on analyses of $3^{\prime}$-terminal nucleotide sequences, these tombusvirus isolates from lettuce and tomato are not as closely related to standard TBSV strains as AMCV and CIRV. These data support the conclusion that the isolates obtained from lettuce and tomato constitute a new tombusvirus species that we propose to name LNSV.

An understanding of tombusvirus genome diversity under agricultural conditions is needed before drawing conclusions from cloned virus sequences obtained from different fields or agricultural areas. To this end, several clones obtained from single plants from one lettuce field and from one tomato greenhouse were sequenced. Clones with minor sequence variants were obtained from single LNSV- and CNV-infected lettuce and tomato plants (maximal sequence divergence $0.85 \%$ ). These sequence variants may either be due to mutations to produce a "quasispecies" or "species cloud" according to the quasispecies concept of viral RNA genomes (15) or to misincorporations of dNTPs during RT-PCR prior to the cloning procedure. In vitro polymerase misincorporation frequencies per site generally average approximately 0.1 to $0.01 \%$ and range between $1 \%$ and less than $0.01 \%$ (39). Regardless, the low level of sequence divergence suggests that isolates of tombusviruses obtained from lettuce and tomato represent minor sequence variants or species clouds of less than $1 \%$ sequence divergence.

TBSV-cherry (PAMV) and TBSV-BS3 strains cause disease outbreaks in tomato in different regions in Spain. It has been suggested that these TBSV strains were introduced independently, and thus, the disease outbreaks must have had different origins (27). Two different tombusviruses are associated with diebackaffected lettuce in California. A new tombusvirus, provisionally called LNSV, was found in the majority of fields tested in California, but the TBSV-cherry strain was recovered from one field in California. All fields affected by dieback disease from which LNSV was isolated were in areas flooded by the Salinas River. In contrast, TBSV-cherry (PAMV) was isolated twice from fields showing dieback-like symptoms that never have been subjected to flooding: a field in Gonzales (isolate L3) and a field in Yuma, AZ (isolate L8). These data also suggest that both LNSV and TBSV-cherry (PAMV) may be involved in lettuce dieback disease in California and Arizona. The presence of LNSV and TBSV-cherry in diseased greenhouse-grown tomatoes also suggests that these tombusviruses play a role in the epidemiology of diseases of tomatoes in the western United States.

The tests conducted in which lettuce plants grown in soil from dieback-affected fields developed dieback symptoms, demonstrating the soilborne nature of the disease. The pathogenicity tests using soil-inoculation of lettuce plants with LNSV-infected $N$. clevelandii plant sap resulted in systemic infection of the lettuce plants and development of typical dieback symptoms including necrotic ring spots on the leaves. This suggests that LNSV is the cause of dieback disease in lettuce. However, TBSV-cherry also produced yellowing symptoms on lettuce leaves when inoculated into the soil.

Lettuce plants sap-inoculated with LNSV developed necrotic lesions on inoculated leaves but not systemic infection. This indicates that initiation of systemic infection of lettuce with LNSV requires infection via the root system. The sterile soil-inoculation experiments strongly suggest that infection with LNSV via the roots can occur in the absence of a fungal vector. However, this does not exclude the possibility that fungal vectors may facilitate transmission under natural conditions. CNV is naturally transmitted to cucumber roots by the soilborne fungus Olpidium bornovanus $(5,8)$. However, soil transmission of $\mathrm{CNV}$ without involvement of a fungal vector has been observed under experi- 
mental conditions (D. A. Rochon, personal communication). The occurrence of tombusviruses in river water has been demonstrated in England and Germany $(21,46)$. The association of lettuce dieback disease with flooded fields near the Salinas River suggests that LNSV was spread by river and irrigation water, explaining the widespread incidence in previously flooded fields in California. Another possible means of dispersal of lettuce dieback disease is by movement of infested soil or by harvesting and processing equipment throughout lettuce growing areas in California and Arizona.

Pathogenicity tests conducted by soil inoculation of tomato plants with the LNSV isolate obtained from diseased greenhousegrown tomatoes, as well as the recovery of other tombusvirus strains, suggest that LNSV alone or in combination with TBSVcherry strain is the cause of this new disease of greenhouse-grown tomatoes. The symptoms of this new disease are different from symptoms previously associated with TBSV strains in tomato $(27,42)$. Fruit from plants with the new disease are not highly deformed and discolored as described for TBSV infection of tomato in Spain. However, fruit does exhibit a transparent appearance in earlier developmental stages, fruit is deeply lobed and there is internal browning $(48,49)$. Similar symptoms in tomato plants in association with TBSV were described once in Turkey (50). Further investigation is needed to clarify whether a correlation exists between occurrence of the disease and infections with LNSV and other tombusviruses, and if different environmental conditions or cultivar reactions play a role in the symptom expression. Occurrence of the disease in greenhouse tomatoes grown in hydroponic culture is consistent with LNSV spreading efficiently in irrigation water.

In one case, a lettuce plant in a dieback-affected field had a mixed infection of LNSV and CNV. However, in contrast to the LNSV isolate, the CNV isolate from lettuce was not transmitted to lettuce plants by inoculation of virus-containing plant sap into sterilized soil. This might be due to the absence of a fungal vector for $\mathrm{CNV}$ and does not prove that $\mathrm{CNV}$ is incapable of producing disease in lettuce. Lettuce plants sap-inoculated with CNV developed necrotic local lesions. Although the role of $\mathrm{CNV}$ in the etiology of dieback disease needs to be evaluated further, we have demonstrated that soil transmission of LNSV is capable of producing dieback symptoms on lettuce plants. The association of $\mathrm{CNV}$ with lettuce plants without dieback symptoms suggests that $\mathrm{CNV}$ does not play a significant role in the etiology of this disease. In lettuce plants, CNV seems to cause only limited damage. However, the repeated recovery of CNV suggests that it may commonly infect lettuce and tomato. The $3^{\prime}$-terminal sequences of $\mathrm{CNV}$ isolates from lettuce and tomato were almost identical, but were 5\% different from the type CNV isolate obtained from Canada. This suggests that the CNV isolates infecting lettuce and tomato from the western part of the United States have a common origin. Additional studies are needed to establish whether these represent a new strain of CNV.

\section{ACKNOWLEDGMENTS}

This work was supported, in part, by a U.S. Department of Agriculture postdoctoral program and the California Lettuce Research Board. We thank A. Jackson, T. Rubio, and R. McDiarmid from the University of California, Berkeley, H. Scholthof from Texas A\&M University, College Station, and D. A. Rochon from Agriculture and Agri-Food Canada, Summerland, for providing antisera for TBSV and CNV isolates and for helpful discussions; L. Rubino from the University of Bari, Italy, for providing full-length clones for CIRV and CymRSV; and H. Scholthof and D. A. Rochon for critical review of the manuscript.

\section{LITERATURE CITED}

1. Allan, W. R., and Davidson, T. R. 1967. Tomato bushy stunt virus from Prunus avium L. I. Field studies and virus characterization. Can. J. Bot.
45:2375-2383

2. Bercks, R., and Lovisolo, O. 1965. Serologischer vergleich von Stämmen des tomatenzwergbusch-virus (tomato bushy stunt virus). J. Phytopathol. 52:96-101.

3. Bohn, G. W. 1953. The important diseases of lettuce. U.S. Dep. Agric. Yearb. Agric. 2452:417-425.

4. Borges, M. D. L., Sequeira, J. C., and Louro, D. 1979. Aparecimento em Portugal do virus do emanjericado do tomateiro (tomato bushy stunt virus). Hospedeiros, morfologia e localizaçao nas celulas de Pimenteiro. Phytopathol. Mediterr. 18:118-122.

5. Campbell, R. N., Sims, S. T., and Lecoq, H. 1995. Virus transmission by host-specific strains of Olpidium bornovanus and Olpidium brassicae. Eur. J. Plant Pathol. 101:273-282.

6. Cherif, C., and Spire, D. 1983. Identification du virus de rabourgrissement buissoneux de la tomate (tomato bushy stunt virus) en Tunisie sur tomate, piment e aubergine: Quelques charactéristiques de la souche tunisiennes. Agronomie 3:701-706.

7. Dalmay, T., Russo, M., and Burgyán, J. 1993. Repair in vivo of altered $3^{\prime}$ terminus of cymbidium ringspot tombusvirus RNA. Virology 192:551-555.

8. Dias, H. F. 1970. Transmission of cucumber necrosis virus by Olpidium cucurbitacearum Barr and Dias. Virology 40:828-839.

9. Fischer, H. U., and Lockhart, B. E. L. 1977. Identification and comparison of two isolates of tomato bushy stunt virus from pepper and tomato in Morocco. Phytopathology 67:1352-1355.

10. Gallitelli, D., Hull, R., and Koenig, R. 1985. Relationships among viruses in the tombusvirus group: Nucleic acid hybridization studies. J. Gen. Virol. 66:1523-1531.

11. Gerik, J. S., Duffus, J. E., Perry, R., Stenger, D. C., and Van Maren, A. F. 1990. Etiology of tomato plant decline in the California desert. Phytopathology 80:1352-1356.

12. Gigante, R. 1955. Il 'rachitismo cespuglioso' del pomoro. Boll. Stn. Patol. Veg. Roma 12:43-56.

13. Hearne, P. Q., Knorr, D. A., Hillman, B. I., and Morris, T. J. 1990. The complete genome structure and synthesis of infectious RNA from clones of tomato bushy stunt virus. Virology 177:141-151.

14. Hillman, B. I., Morris, T. J., and Schlegel, D. E. 1985. Effects of lowmolecular-weight RNA and temperature on tomato bushy stunt virus symptom expression. Phytopathology 75:361-365.

15. Holland, J. 1993. Replication error, quasispecies populations, and extreme evolution rates of RNA viruses. Pages 203-218 in: Emerging Viruses. S. S. Morse, ed. Oxford University Press, New York.

16. Hollings, M., and Stone, O. M. 1975. Serological and immunoelectrophoretic relationships among viruses in the tombusvirus group. Ann. Appl. Biol. 80:37-48.

17. Jagger, I. C. 1928. The brown blight disease of lettuce. (Abstr.) Phytopathology 18:949-950.

18. Jagger, I. C. 1931. Lettuce breeding for disease resistance progresses rapidly. U.S. Dep. Agric. Yearb. Agric. 1192:348-350.

19. Jagger, I. C. 1940. Brown blight of lettuce. Phytopathology 30:53-64.

20. Jagger, I. C., Whitaker, T. W., Uselman, J. J., and Owen, W. M. 1941. The Imperial strains of lettuce. U.S. Dep. Agric. Circ. 596.

21. Koenig, R. 1988. Detection in surface waters of plant viruses with known and unknown natural hosts. Pages 305-313 in: Developments in Applied Biology. II. Viruses with Fungal Vectors. J. I. Cooper and M. J. C. Asher, eds. Association of Applied Biologists, Wellesbourne, U.K.

22. Koenig, R., and Gibbs, A. 1986. Serological relationship among tombusviruses. J. Gen. Virol. 67:75-82.

23. Koenig, R., and Kunze, L. 1982. Identification of tombusvirus isolates from cherry in Southern Germany as Petunia asteroid mosaic virus. J. Phytopathol. 103:361-368.

24. Laemmli, U. K. 1970. Cleavage of structural proteins during assembly of the head of bacteriophage T7. Nature 227:680-685.

25. Liu, H. Y., Duffus, J. E., and Wisler, G. C. 1996. Etiology of vascular necrosis syndrome of sugarbeet. Pages 161-164 in: Int. Symp. Working Group on Plant Viruses with Fungal Vectors, 3rd. J. L. Sherwood and C. M. Rush, eds. American Society of Sugar Beet Technologists, Denver.

26. Liu, H.-Y., Sears, J. L., Obermeier, C., Wisler, G. C., Ryder, E. J., Duffus, J. E., and Koike, S. T. 1999. First report of tomato bushy stunt virus isolated from lettuce. Plant Dis. 83:301.

27. Luis-Arteaga, M., Rodríguez-Cerezo, E., Fraile, A., Sáez, E., and GarcíaArenal, F. 1996. Different tomato bushy stunt virus strains that cause disease outbreaks in Solanaceous crops in Spain. Phytopathology 86:535-542.

28. Martelli, G. P. 1971. Tomato bushy stunt virus. No. 69 in: Description of Plant Viruses. Commonw. Mycol. Inst./Assoc. Appl. Biol., Kew, England.

29. Martelli, G. P. 1981. Tombusviruses. Pages 61-90 in: Handbook of Plant Virus Infections and Comparative Diagnosis. E. Kurstak, ed. Elsevier North-Holland Biomedical Press, Amsterdam.

30. Martelli, G. P., Gallitelli, D., and Russo, M. 1988. Tombusviruses. Pages 13-72 in: The Plant Viruses. Vol. 3. R. Koenig, ed. Plenum Press, 
New York.

31. Martinez, J. A., Galindo, J. A., and Rodriguez, R. M. 1974. Estudio sobre la enfermedad del 'Pinto' del jitomate (Lycopersicon sculentum Mill) en la region de Actopan, HGO. Agrociencia 18:71-78.

32. McKeen, C. D. 1959. Cucumber necrosis virus. Can. J. Bot. 37:913-925.

33. Moore, W. C. 1947. Diseases of crop plants. Minist. Agric. Fish. Bull. 126.

34. Moore, W. C. 1948. Diseases of crop plants. Minist. Agric. Fish. Bull. 139.

35. Novák, J. B., Nováková, J., and Lanzová, J. 1981. Dukaz viru zakrslosti rajcete (tomato bushy stunt virus) na hlavkovem salatu. Sb. UVTIZ Ochr. Rostl. 17:241-245.

36. Obermeier, C., Sears, J. L., Wisler, G. C., Liu, H. Y., Schlueter, K. O., Ryder, E. J., Duffus, J. E., and Koike, S. T. 1999. Characterization of a new tomato bushy stunt-related tombusvirus associated with lettuce dieback disease in California. (Abstr.) Phytopathology 89(suppl.):S57.

37. Perriere, G., and Gouy, M. 1996. WWW-query: An on-line retrieval system for biological sequence banks. Biochimie 78:364-369.

38. Pontis, R. E., García, O., and Feldman, J. M. 1968. Tomato bushy stunt virus on tomato crops in Argentina. Plant Dis. Rep. 52:676-677.

39. Preston, B. D., Zakour, R. A., Singer, B., and Loeb, L. A. 1988. Fidelity of base selection by DNA polymerases. Site-specific incorporations of base analogs. Pages 196-207 in: DNA Replication and Mutagenesis. R. E. Moses and W. C. Summers, eds. The American Society for Microbiology, Washington, D.C.

40. Rochon, D. M., and Tremaine, J. H. 1989. Complete nucleotide sequence of the cucumber necrosis virus genome. Virology 169:251-259.
41. Rodríguez-Cerezo, E., and Shaw, J. G. 1991. Two newly detected nonstructural viral proteins in potyvirus-infected cells. Virology 185:572-579.

42. Smith, K. M. 1935. A new virus disease of tomato. Ann. Appl. Biol. 22:731-741.

43. Steere, R. L. 1953. Strains of tomato bushy-stunt virus. (Abstr.) Phytopathology 43:485.

44. Thompson, J. D., Gibson, T. J., Plewniak, F., Jeanmougin, F., and Higgins, D. G. 1997. The ClustalX windows interface: Flexible strategies for multiple sequence alignment aided by quality analysis tools. Nucleic Acids Res. 24:4876-4882.

45. Tobwin, H., Staehelin, T., and Gordon, J. 1979. Electrophoretic transfer of proteins from polyacrylamide gels to nitrocellulose sheets: Procedure and some applications. Proc. Natl. Acad. Sci. USA 76:4350-4354.

46. Tomlinson, J. A., and Faithfull, E. M. 1984. Studies on the occurrence of tomato bushy stunt virus in English rivers. Ann. Appl. Biol. 104:485495.

47. Valverde, R. A., Nameth, S. T., and Jordan, R. L. 1990. Analysis of double-stranded RNA for plant virus diagnosis. Plant Dis. 74:255-258.

48. Wisler, G. C. 2000. A new disease is spreading. Researchers are on the trail of tomato dieback, a disease that affects greenhouse tomatoes. 48th Western ed. Am. Veg. Grower, Greenhouse Insider 4:6-8.

49. Wisler, G. C., Sears, J. L., Liu, H.-Y., Obermeier, C., and Duffus, J. E. 1999. A new disease of greenhouse-grown tomatoes caused by tomato bushy stunt virus (TBSV). (Abstr.) Phytopathology 89(suppl.):S85.

50. Yilmaz, M. A. 1981. Virus particles associated with diseases of tomato and lettuce in Turkey. Phytopathol. Mediterr. 20:79-80. 